\title{
AMHTS に抢ける連続受診者の健康度変化の検討
}

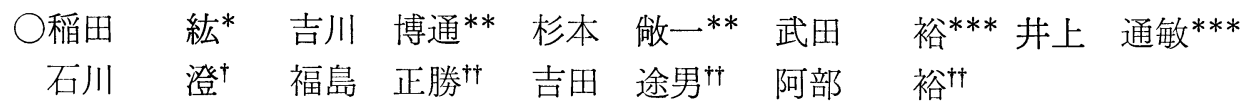

自動化総合健診システム（AMHTS）において，受診 者との面接時に医師が必要とする行動の支援をめざし て, (1)連続受診者についての個人正常值の算出之個人の 正常範囲をはずれた場合の注意の喚起, (2)パーソナルコ ンピュータを使用した受診者のライフスタイルに関する 教育など，幾つかの機能を有するコンピュータによる受 晾者指導教育支援システムの開発を進めている。

これらの機能のうち, 上記の(1)関連して, 連続受倝 者の健部データがその個人の正常範囲を冕脱しているか 否かの健康度変化の評価を, 三角多項式グラフ法により 行なうととを試みた。そして, 結果をパーソナルコンピ ュータのディスプレイ装置に図形として表示したとと ろ, 本方法の妥当性とともに, 二, 三の問題点の存する ことが窮われた。

今回, これらの問題点のうち, 三角多項式にあてはめ る検査項目のデータの順序に関して検討を試みた。

連続受診者の時系列データにおりる異常を検出する 方法として，昨年の本大会で報告したように，D．F. Andrews により提案された三角多項式グラフ法を応用 した。

この方法は, AMHTS の連続受彰者の多項目時系列 データを $X_{i}=\left(x_{1 i}, x_{2 i}, \cdots, x_{p i}\right)$ とするとき $(p:$ 健診項 目数, $i=1,2, \cdots$, : 何回目の受診かを示す受診回数で通 常は年単位), $p$ 次元実数空間 $R^{p}$ 内の 1 点として表 わされた $x_{i}$ を, 写像関数 $f_{t}(X)=x_{1} / \sqrt{2}+x_{2} \sin t+$ $x_{3} \cos t+x_{4} \sin 2 t+x_{5} \cos 2 t+\cdots$ により， $R^{p}$ 加ら $R^{2}$ へ,すなわち， 2 次元空間へ変換しようとするものであ る。乙の $f_{t}(X)$ の形を見ると, 元の変数 $\left(x_{1}, x_{2}, \cdots, x_{p}\right)$ は等しく重みづけされておらず, 変数の幾つかは低周波 の循環変動成分に対応づけられ, 残りは高周波の循環変 動成分に対応づけられていることが分かる。これらのプ ロットは，低周波の方が高周波よりも目につきやすいと

\footnotetext{
Evaluation of Changes in Time Serial Data of AMHTS Examinees

* 国立循環器病センター研究所

** 住友生命総合健㗒システム

$* * *$ 大阪大学病院医療情報部

十 香川医科大学

${ }^{++}$国立大阪病院
}

とから， $x_{1}$ を最も重要な変数に結びつけ， $x_{2}$ を 2 番目 に重要な変数に対応させるというような方法が有用と考 えられる。本研究では上記の変数として, 個体の特徵を 総合的にとらえるのに適していると思われる 19 の検査 項目を用いているが，乙れらの項目間における重要性に 関して, 確固たる根拠に基づく順序づけを行うこ之は困 難である。そてで, 対象である昭和 51 年 6 月から住友生 命総合健診システムを 5 回以上反復受診した 20 歳代か ら 60 歳代までの男子 50 名のデータを用いて主成分分析 を行い，その第 1 主成分の因子負荷量の絶対值の大きい 順に $x_{1}, x_{2}, \cdots$ という変数をあてはめるようにした。

その結果, 検査項目の順序は, 赤血球数(12), GOT (9), 空腹時血糖(11)， $50 \mathrm{~g}$ ブドウ糖負荷 1 時間後血糖值 (OGTT) (17), 体重(1), アルブミン(14)，へマトクリット (13)，血清総コレステロール(10), 拡張期血圧(5), 収縮期血 圧(4), 聴力(2), 総蛋白 (7), 胸部X線心胸比(19, $\mathrm{LDH}$ (16, 尿酸15，アルカリフォスファターゼ18，尿素窒素(8), PSP 15 分值(6), 肺機能 1 秒率(3)の順となった。

乙の順 (順序 1 ) で写像関数の変数 $x_{1}, x_{2}, \cdots$ にあて はめ，まず健常な受診者の 5 回の健診データについて三 角多項式グラフによる曲線を求め, 昨年度に報告した順 序 (上記の各検査項目の後に記した番号の順で, 乙れを 順序 2 とする）による曲線と比較した。次いで, 3 回目 之 4 回目における収縮期血圧, 拡張期血圧が異常で, OGTT あやや高值を示す受診者のデータについて，同 じ処理を行った。

健常な受診者では，両方の順序による曲線群に大きな 差異はなく, それぞれの各回の曲線にも極端な違いは少 なかった。乙れに対して, 異常例では, それぞれの曲線 の 3 回目, 4 回目の曲線で他の曲線群より振幅が大きく, 位相もずれており, 異常を示唆するものであったが, 順 序 1 亿よる曲線の方が顕著で, 異常の検出がより容易な ことが認められた。

以上より，今回試みた主成分分析を応用した三角多項 式グラフ法の有用性がうかがわれた。

(本研究は, (財) 健康科学振興財団昭和 63 年度研究助 成抢よび厚生省昭和 63 年度厚生科学研究費補助金 (新医 療技術研究事業）により実施された。） 